\title{
RADIOACTIVITY OF GRANITIC ROCKS FROM NORTHERN GREECE
}

\author{
Papadopoulos A. ${ }^{1}$, Christofides G. ${ }^{1}$, Papastefanou C. ${ }^{2}$, Koroneos A. ${ }^{1}$ \\ and Stoulos S. ${ }^{2}$ \\ ${ }^{1}$ Department of Mineralogy-Petrology-Economic Geology, School of Geology, Aristotle University of \\ Thessaloniki,541 24,Thessaloniki,argpapad@geo.auth.gr,christof@geo.auth.gr,koroneos@geo.auth.gr. \\ ${ }^{2}$ Laboratory of Atomic and Nuclear Physics, Aristotle University of Thessaloniki, 541 24, Thessaloniki, \\ papastefanou@physics.auth.gr, stoulos@auth.gr.
}

\begin{abstract}
Forty-nine samples from several plutons in northern Greece have been studied for their activity concentrations of ${ }^{40} \mathrm{~K},{ }^{226} \mathrm{Ra}$ and ${ }^{232} \mathrm{Th}$ by using gamma-ray spectroscopy. The activities of ${ }^{40} \mathrm{~K},{ }^{226} \mathrm{Ra}$ and ${ }^{232}$ Th of the majority of the samples exceed the average level of these radionuclides in soil and building materials. Samples of basic composition have very low concentrations of radionuclides while intermediate and acid rocks are more enriched in ${ }^{40} \mathrm{~K},{ }^{226} \mathrm{Ra}$ and ${ }^{232} \mathrm{Th}$ and their decay products. In order to assess the radiological impact from the investigated rocks, absorbed gamma dose rate $\left(D_{a}\right)$, annual effective dose $\left(H_{E}\right)$, activity index $(A I)$ and gamma-ray index $\left(I_{\gamma}\right)$ were estimated. The activity concentrations and hazard indices were compared to those of plutonic rock samples from all over the world, as well as other building materials. The average of hazard indices of Greek granites is below 'world' average in all cases. Moreover, it is still bellow the criteria of UNSCEAR (2000). Therefore, at least from radiological point of view and for the investigated rocks, the use of granites from northern Greece as building materials is recommended.
\end{abstract}

Key words: granite, natural radioactivity, radiation, dose assessment, northern Greece.

\section{Introduction}

In igneous petrology, granite is a prevailing rock-type describing acid plutonic rocks having a particular mineralogy and geochemistry. However, in dimension stone market the term granite includes a variety of igneous and metamorphic rock-types, used as building materials. In recent years, use of granite as a decor material in buildings (indoors and outdoors) and monuments has globally increased, due to its durability and appearance. In this paper, the term "granite" is used for the plutonic rocks under study including granitic and monzonitic as well as gabbroic rocks.

Radioisotopes that are found in the environment can be classified as naturally occurring radionuclides that are components of the earth's crust since its formation (e.g. ${ }^{238} \mathrm{U},{ }^{235} \mathrm{U},{ }^{232} \mathrm{Th}$ and ${ }^{40} \mathrm{~K}$ and their decay products), cosmogenic radioisotopes (radioisotopes that are produced by the interaction between cosmic radiation and the atmosphere $\left(\right.$ e.g. ${ }^{14} \mathrm{C},{ }^{10} \mathrm{Be},{ }^{44} \mathrm{Ti}$ and $\left.{ }^{22} \mathrm{Na}\right)$ and finally artificially produced radionuclides that are produced in nuclear reactors (e.g. ${ }^{90} \mathrm{Sr}$ and ${ }^{137} \mathrm{Cs}$ ). Natural radionuclides can be found in soil, rocks, water, air, food, building materials, etc.

The study of natural radioactivity present in rocks and ornament stones, such as granite, is an im- 


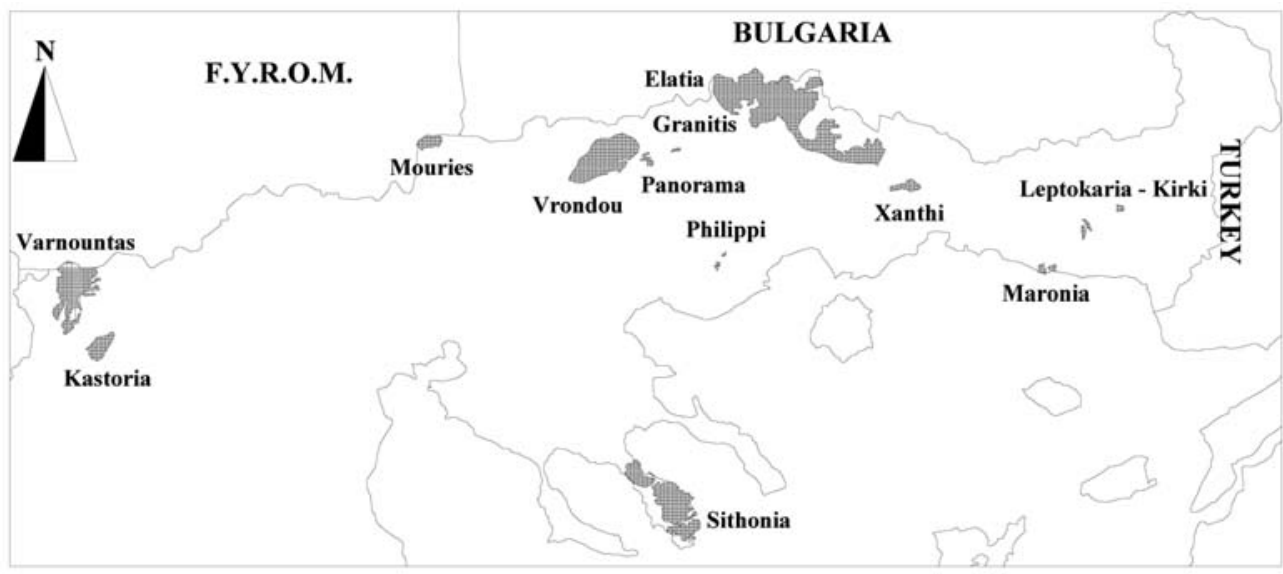

Fig. 1: Sketch map of northern Greece, presenting the location of plutons from which the granite samples were obtained.

portant subject in environmental radiological protection (Anjos et al., 2005) as it provides the possibility to assess any associated health hazard. This contribution aims at investigating the natural radioactivity level of selected granites from north Greece in order to assess their radiation dose exposure and give information about the potential use of them as building materials.

\section{Materials and methods}

The samples studied were taken from Pelagonian zone (Varnountas and Kastoria plutons), Circum Rhodope Zone (Sithonia and Maronia plutons), Serbomacedonian Massif (Mouries pluton) and Rhodope Massif (Vrontou, Elatia, Granitis, Panorama, Xanthi, Philippi, and Leptokaria-Kirki plutons) (Fig. 1). The mineralogy of the selected samples is presented in Table 1, while the rock-type along with the location of plutons from which the samples were obtained, is presented in Table 2 . The petrographic classification was based on the QAP tertiary diagram (I.UG.S., 1973).

Details on the petrography and geochemistry of the above plutonic rocks can be found in Christofides et al., 1998 and references therein, Koroneos, 1991; Grigoriadou et al., 2003; D’ Amico et al., 1990 and Christofides et al., 1999.

The activity concentration of natural radionuclides was measured by gamma-ray spectrometry for 20 granite samples. Additionally, 29 samples from the same area were used from the literature (Karavasili et al., 2005).

In particular, the content of ${ }^{226} \mathrm{Ra},{ }^{232} \mathrm{Th}$ and ${ }^{40} \mathrm{~K}$ of each sample was measured, as these occur in relatively high levels in the majority of the building materials and they represent the main external source of irradiation to the human body.

All samples were crushed into grains less than $400 \mu \mathrm{m}$ in diameter, oven-dried at $60{ }^{\circ} \mathrm{C}$ to constant weight, well blended and measured using two different high-resolution gamma ray spectrometry systems. The first one consisted of a high purity (HP) Ge coaxial detector with $42 \%$ efficiency and $2.0 \mathrm{keV}$ resolution at $1.33 \mathrm{MeV}$ gamma-ray photons, shielded by $4^{\prime \prime} \mathrm{Pb}, 1 \mathrm{~mm} \mathrm{Cd}$ and $1 \mathrm{~mm} \mathrm{Cu}$ and the second one consisted of a low energy (LE) Ge planar detector with $0.7 \mathrm{KeV}$ resolution at 122 keV gamma-ray photons, shielded by $1.3^{\prime \prime} \mathrm{Pb}, 1 \mathrm{~mm} \mathrm{Cd}$ and $1 \mathrm{~mm} \mathrm{Cu}$. The efficiency calibration of 
Table 1. Mineralogy (modal composition) of selected samples

\begin{tabular}{|c|c|c|c|c|c|c|c|c|c|}
\hline sample & $\mathbf{Q z}$ & Kf & PI & $\mathbf{H b}$ & $\mathbf{B i}$ & Mu & $\mathbf{P x}$ & Oth & Tot \\
\hline MP-6 & 1.2 & 20.2 & 50.5 & 8.8 & 12.7 & 0.0 & 1.1 & 5.5 & 100.0 \\
\hline MP-77 & 14.4 & 37.0 & 28.2 & 16.4 & 0.1 & 0.0 & 0.0 & 3.9 & 100.0 \\
\hline XMZ-501 & 4.1 & 39.4 & 28.2 & 0.2 & 11.3 & 0.0 & 16.0 & 0.8 & 100.0 \\
\hline MP-3 & 6.6 & 31.0 & 35.9 & 11.0 & 12.4 & 0.0 & 0.0 & 3.1 & 100.0 \\
\hline MP-38 & 2.3 & 31.0 & 40.6 & 0.7 & 9.5 & 0.0 & 15.0 & 0.9 & 100.0 \\
\hline MP-53 & 1.8 & 20.6 & 28.4 & 14.7 & 7.5 & 0.0 & 21.5 & 5.5 & 100.0 \\
\hline STH-162 & 35.4 & 22.9 & 24.3 & 0.0 & 9.4 & 7.8 & 0.0 & 0.2 & 100.0 \\
\hline MP-90 & 17.1 & 33.3 & 31.6 & 7.8 & 3.6 & 0.0 & 2.1 & 4.5 & 100.0 \\
\hline $\mathrm{X}-270$ & 17.8 & 20.0 & 42.2 & 7.0 & 8.3 & 0.0 & 0.0 & 2.2 & 100.0 \\
\hline MP-501* & 37.4 & 45.9 & 8.5 & 5.5 & 1.7 & 0.0 & 0.0 & 0.9 & 100.0 \\
\hline P-5** & 23.5 & 42.5 & 24.6 & 7.5 & 0.0 & 0.1 & 0.0 & 1.8 & 100.0 \\
\hline $\mathbf{I}-3 * *$ & 43.7 & 23.9 & 24.4 & 4.4 & 0.0 & 0.0 & 0.0 & 2.6 & 100.0 \\
\hline STH-5* & 44.0 & 14.7 & 34.1 & 3.9 & 3.1 & 0.0 & 0.0 & 0.2 & 100.0 \\
\hline STH-13* & 30.4 & 23.8 & 41.4 & 2.3 & 1.3 & 0.0 & 0.0 & 0.8 & 100.0 \\
\hline STH-118 & 38.0 & 7.1 & 45.6 & 9.0 & 0.0 & 0.0 & 0.0 & 0.3 & 100.0 \\
\hline STH-450 & 30.0 & 12.2 & 35.5 & 11.3 & 0.0 & 6.7 & 0.0 & 4.3 & 100.0 \\
\hline D-8b*** & 16.4 & 0.8 & 60.4 & 15.6 & 0.0 & 0.0 & 0.0 & 6.8 & 100.0 \\
\hline D-15*** & 26.2 & 35.6 & 32.2 & 2.0 & 1.2 & 0.0 & 0.0 & 2.8 & 100.0 \\
\hline DSK-17**** & 18.8 & 0.0 & 56.5 & 22.0 & 0.0 & 0.2 & 0.0 & 2.5 & 100.0 \\
\hline $\mathrm{A}-13 * * *$ & 28.7 & 24.7 & 37.0 & 0.0 & 3.0 & 0.0 & 0.0 & 6.6 & 100.0 \\
\hline G-2*** & 34.8 & 44.7 & 18.1 & 2.0 & 0.0 & 0.0 & 0.0 & 0.4 & 100.0 \\
\hline YD-12* & 11.2 & 22.3 & 45.5 & 7.8 & 0.0 & 8.8 & 0.0 & 4.3 & 100.0 \\
\hline
\end{tabular}

(Qz: Quartz, Kf: K-feldspars, Pl: Plagioclase, Hb: Hornblende, Bi: Biotite, Mu: Muscovite, Px: Pyroxenes, Oth: Others, Tot: Total)

* (Karavasili, 2004), $* *($ Koroneos, 1991), $* * *($ Soldatos, 1985).

the gamma-ray spectrometry systems was performed with the radionuclide specific efficiency method in order to avoid any uncertainty in gamma ray intensities, as well as the influence of coincidence summation and self-absorption effects of the emitting gamma-ray photons. A set of high quality certified reference materials (IAEA, RG-sets) was used, with densities similar to the building materials measured after pulverization. Cylindrical geometry $(\varnothing: 55 \mathrm{~mm}, \mathrm{~h}=20 \mathrm{~mm}$ ) was used assuming that the radioactivity is homogenously distributed in the measuring samples. The measurement duration was up to $200.000 \mathrm{~s}$ and was carried out in the Laboratory of Atomic and Nuclear Physics, Department of Physics, Aristotle University of Thessaloniki.

\section{Results and discussion}

The specific activities of ${ }^{40} \mathrm{~K},{ }^{226} \mathrm{Ra}$ and ${ }^{232} \mathrm{Th}$ measured in the granite samples are presented in Table 2. The specific activity of ${ }^{40} \mathrm{~K}$ has a much wider range $\left(64-1632 \mathrm{~Bq} \cdot \mathrm{kg}^{-1}\right)$ than those of ${ }^{226} \mathrm{Ra}$ and ${ }^{232} \mathrm{Th}$, which are respectively 1,4-315,4 and 2-372,2 $\mathrm{Bq} \cdot \mathrm{kg}^{-1}$. The average values of ${ }^{40} \mathrm{~K},{ }^{226} \mathrm{Ra}$ and ${ }^{232} \mathrm{Th}$ are $929,3,77,3$ and $91,4 \mathrm{~Bq} \cdot \mathrm{kg}^{-1}$, respectively. 
The worldwide average and range (within brackets) of natural radioactivity background levels in soil are 400 (140-850), 35 (17-60) and 30 (11-64) $\mathrm{Bq} \cdot \mathrm{kg}^{-1}$, respectively for ${ }^{40} \mathrm{~K},{ }^{226} \mathrm{Ra}$ and ${ }^{232} \mathrm{Th}$ (UNSCEAR, 2000). As it was expected, the average activity mass concentrations of the radionuclides measured in the granites from northern Greece are above the average activity levels given in the above UNSCEAR, 2000 report for soil (Pavlidou et al., 2006; Karavasili et al., 2005; Stoulos et al., 2003).

According to UNSCEAR (1993), the world average of natural radioactivity levels of ${ }^{40} \mathrm{~K},{ }^{226} \mathrm{Ra}$ and ${ }^{232} \mathrm{Th}$ in building materials is 500,50 and $50 \mathrm{~Bq} \cdot \mathrm{kg}^{-1}$, respectively. Taking into account the measured levels of natural radioactivity in Greek building materials by this study as well as by other Greek researchers (Siotis and Wrixon, 1984, Papastefanou et al., 1984; Pakou et al., 1994; Savidou et al., 1995; Petropoulos et al., 2002) and considering that most of Greek dwellings were constructed mainly by clay bricks and concrete in weight proportion $40-60 \%$, the specific activities of natural radionuclides in building materials that appeared in a typical Greek room are the following: ${ }^{40} \mathrm{~K}$, $550 \mathrm{~Bq} \cdot \mathrm{kg}^{-1}$; U-series, $35 \mathrm{~Bq} \cdot \mathrm{kg}^{-1}$ and Th-series, $32 \mathrm{~Bq} \cdot \mathrm{kg}^{-1}$ (Stoulos et al., 2003). This means that granites contain a much higher amount of radionuclides presumably caused by the presence of Uand Th-rich minerals in them. For example, tetravalent Th and $U$ may be isomorphously substituting in the Ca position in allanite, sphene and apatite. Ce-rich monazite rivals zircon in common rocks as a ubiquitous and important carrier of Th. To a much lesser extend $U$, was also found in monazite, apparently also in isomorphic substitution. The situation is reversed in xenotime, where $\mathrm{U}$ was generally more abundant than Th. Uraninite and thorianite are two other minerals found in common rocks that are believed to contain $\mathrm{Th}$ and $\mathrm{U}$ as essential components in regular crystal structural positions (Adams et al., 1959). According to Faure (1986), U- and Th-rich minerals can be found in acid igneous rocks than in basic rocks. This can be explained by the incompatibility of both $\mathrm{U}$ and Th during partial melting and fractional crystallization processes $(\mathrm{Kd}<1)$, leading thus in the remaining of $\mathrm{U}$ and $\mathrm{Th}$ in the melt and their incorporation in minerals of acid rocks.

Activity concentrations of ${ }^{40} \mathrm{~K},{ }^{226} \mathrm{Ra}$ and ${ }^{232} \mathrm{Th}$ in granite samples from various countries of the world, including Greece, have been compiled from literature and are presented in Table 3 for comparison. The 'world' weighted average calculated from the above measurements has also been used for comparison. The activity concentrations of these radionuclides vary over a wide range. Their average activity concentration in Greek granite samples is below the 'world' average in all cases. The minimum and maximum ${ }^{40} \mathrm{~K}$ were found in the granite from Wadi Karim and Gable El Aradiya in Egypt, respectively. The granite of Gabble Gattar II in Egypt contains the maximum and that of Africa has the minimum ${ }^{226} \mathrm{Ra}$. The maximum ${ }^{232} \mathrm{Th}$ was found in the Pakistani granite and the minimum in the granite of Gable El Aradiya in Egypt.

In order to assess the radiological impact of granites used as building materials, the model of a rec-

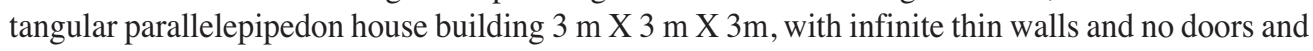
windows (standard room model) was commonly considered (UNSCEAR, 1993)

A variety of radiation hazard indices representing different methods to assess the collective effect of mass concentrations of ${ }^{40} \mathrm{~K},{ }^{226} \mathrm{Ra}$ and ${ }^{232} \mathrm{Th}$ was used:

1) Absorbed gamma dose rate $\left(\mathbf{D}_{\mathrm{a}}\right)$. The measured activity concentrations of ${ }^{238} \mathrm{U}\left({ }^{226} \mathrm{Ra}\right),{ }^{232} \mathrm{Th}$ and ${ }^{40} \mathrm{~K}$ is converted into doses $\left(\mathrm{nGy} \cdot \mathrm{h}^{-1} \cdot \mathrm{Bq}^{-1} \cdot \mathrm{kg}^{-1}\right.$ ) (where Gy=Gray and $\mathrm{Bq}=$ Becquerel) by applying the factors $0.462,0.604$ and 0.0417 for $\mathrm{U}\left({ }^{226} \mathrm{Ra}\right)$, Th and $\mathrm{K}$, respectively (UNSCEAR, 1993). These factors were used to calculate the total absorbed gamma dose rate in air at $1 \mathrm{~m}$ above the ground level using the following equation:

$$
\mathrm{D}_{\mathrm{a}}\left(\mathrm{nGy} \cdot \mathrm{h}^{-1}\right)=0.462 \mathrm{C}_{\mathrm{U}}+0.604 \mathrm{C}_{\mathrm{Th}}+0.0417 \mathrm{C}_{\mathrm{K}}
$$


Table 2. Activity concentrations of ${ }^{40} \mathrm{~K},{ }^{226} \mathrm{Ra}$ and ${ }^{232} \mathrm{Th}$ in $\mathrm{Bq} \cdot \mathrm{kg}^{-1}$ along with their total uncertainties of the studied samples.

\begin{tabular}{|c|c|c|c|c|c|}
\hline Sample & Location & Rock-type & ${ }^{226} \mathbf{R a}$ & ${ }^{232} \mathrm{Th}$ & ${ }^{40} \mathrm{~K}$ \\
\hline GAE-1 & Xanthi & gabbro & $15.6 \pm 0$ & $18.2 \pm 0$ & $291.0 \pm 5$ \\
\hline GAE-9 & Xanthi & gabbro & $42.7 \pm 1$ & $50.7 \pm 1$ & $685.0 \pm 9$ \\
\hline GAE-11 & Xanthi & gabbro & $5.3 \pm 0$ & $6.5 \pm 1$ & $175.0 \pm 4$ \\
\hline SB-55* & Vrondou & gabbro & $1.4 \pm 0$ & $2.0 \pm 0$ & $68.0 \pm 4$ \\
\hline NG-5* & Xanthi & gabbro & $2.5 \pm 0$ & $6.5 \pm 0$ & $64, .0 \pm 3$ \\
\hline MP-6 & Maronia & hb-bi monzogabbro & $65.9 \pm 1$ & $71.8 \pm 1$ & $810.0 \pm 10$ \\
\hline MZ-500* & Xanthi & bi-px-qz-monzodorite & $170.0 \pm 2$ & $189.0 \pm 3$ & $1304.0 \pm 22$ \\
\hline MP-5 & Varnountas & hb-bi-qz-monzonite & $61.4 \pm 1$ & $79.5 \pm 1$ & $1027.0 \pm 12$ \\
\hline KR-9* & Varnountas & hb-bi-qz-monzonite & $50.0 \pm 1$ & $78.0 \pm 1$ & $956.0 \pm 14$ \\
\hline SB-41* & Vrondou & hb-qz-monzonite & $109.0 \pm 1$ & $113.0 \pm 2$ & $1110.0 \pm 14$ \\
\hline YD-12* & Philippi & bi-hb-qz-monzodiorite & $28.0 \pm 1$ & $39.0 \pm 1$ & $709.0 \pm 10$ \\
\hline L-23* & Leptokaria-Kirki & bi-px-hb-qz-monzonite & $64.0 \pm 1$ & $59.0 \pm 1$ & $882.0 \pm 13$ \\
\hline MP-77 & Maronia & hb-qz-monzonite & $123.4 \pm 1$ & $124.9 \pm 2$ & $1146.0 \pm 13$ \\
\hline P-6* & Panorama & qz-monzonite & $122.0 \pm 1$ & $143.0 \pm 2$ & $1177.0 \pm 16$ \\
\hline XMZ-501 & Xanthi & bi-px-qz-monzonite & $169.2 \pm 1$ & $188.2 \pm 2$ & $1172.0 \pm 14$ \\
\hline MP-3 & Maronia & hb-bi-qz-monzonite & $106.7 \pm 1$ & $110.0 \pm 1$ & $954.0 \pm 12$ \\
\hline MP-38 & Maronia & bi-px-monzonite & $146.2 \pm 1$ & $148.5 \pm 2$ & $924.0 \pm 11$ \\
\hline MP-53 & Maronia & bi-hb-px-monzonite & $51.4 \pm 1$ & $50.0 \pm 1$ & $663.0 \pm 10$ \\
\hline MR-11* & Maronia & hb-bi-px-mozonite & $97.0 \pm 1$ & $99.0 \pm 1$ & $1051.0 \pm 14$ \\
\hline SB-36* & Vrondou & hb-syenite & $136.0 \pm 1$ & $152.0 \pm 2$ & $1466.0 \pm 17$ \\
\hline DSK-17* & Elatia & bi-tonalite & $41.0 \pm 1$ & $80.0 \pm 1$ & $524.0 \pm 10$ \\
\hline D-8b* & Elatia & bi-tonalite & $44.0 \pm 1$ & $82.0 \pm 1$ & $748.0 \pm 10$ \\
\hline STH-162 & Sithonia & two mica granite & $45.2 \pm 1$ & $28.8 \pm 1$ & $751.0 \pm 10$ \\
\hline STH-170 & Sithonia & two mica granite & $29.0 \pm 1$ & $29.4 \pm 1$ & $603.0 \pm 10$ \\
\hline STH-5* & Sithonia & granodiorite & $38.0 \pm 1$ & $43.0 \pm 1$ & $693.0 \pm 9$ \\
\hline STH-118* & Sithonia & bi-granodiorite & $69.0 \pm 1$ & $80.0 \pm 1$ & $777.0 \pm 10$ \\
\hline STH-450* & Sithonia & hb-bi-granodiorite & $56.0 \pm 1$ & $77.0 \pm 1$ & $754.0 \pm 14$ \\
\hline D-5* & Elatia & bi-granodiorite & $41.0 \pm 1$ & $77.0 \pm$ & $546.0 \pm 11$ \\
\hline MP-501* & Mouries & bi-granite & $73.0 \pm 1$ & $95.0 \pm 1$ & $1386.0 \pm 15$ \\
\hline P-5 & Varnountas & bi-granite & $44.0 \pm 1$ & $88.1 \pm 1$ & $1104.0 \pm 13$ \\
\hline SB-50* & Vrondou & hb-granite & $69.0 \pm 1$ & $70.0 \pm 1$ & $717.0 \pm 12$ \\
\hline L-4* & Vrondou & hb-granite & $54.0 \pm 1$ & $75.0 \pm 1$ & $919.0 \pm 12$ \\
\hline TS-10* & Vrondou & hb-granite & $90.0 \pm 1$ & $138.0 \pm 2$ & $1460.0 \pm 16$ \\
\hline G-6* & Granitis & hb-bi-granite & $106.0 \pm 1$ & $100.0 \pm 1$ & $1060.0 \pm 13$ \\
\hline MP-90 & Maronia & hb- granite & $315.4 \pm 1$ & $372.2 \pm 4$ & $1420.0 \pm 16$ \\
\hline STH-6* & Sithonia & granite & $68.0 \pm 1$ & $64.0 \pm 1$ & $689.0 \pm 11$ \\
\hline B-7* & Vrondou & granite & $88.0 \pm 1$ & $123.0 \pm 2$ & $993.0 \pm 13$ \\
\hline D-15* & Elatia & granite & $46.0 \pm 1$ & $130.0 \pm 2$ & $1448.0 \pm 19$ \\
\hline A-13* & Elatia & granite & $231.0 \pm 1$ & $49.0 \pm 1$ & $1232.0 \pm 16$ \\
\hline
\end{tabular}


Table 2. Continued

\begin{tabular}{|l|c|c|c|c|c|}
\hline \multicolumn{1}{|c|}{ Sample } & Location & Rock-type & ${ }^{\mathbf{2 2 6}} \mathbf{R a}$ & ${ }^{\mathbf{2 3 2}} \mathbf{T h}$ & ${ }^{\mathbf{4 0}} \mathbf{K}$ \\
\hline G-2* & Granitis & granite & $141.0 \pm 1$ & $195.0 \pm 3$ & $1632.0 \pm 21$ \\
\hline PR-27* & Panorama & granite & $56.0 \pm 1$ & $66.0 \pm 1$ & $987.0 \pm 14$ \\
\hline PE-11 & Kastoria & granite & $44.7 \pm 1$ & $50.2 \pm 1$ & $973.0 \pm 12$ \\
\hline TH-5 & Kastoria & granite & $70.0 \pm 1$ & $68.6 \pm 1$ & $1099.0 \pm 13$ \\
\hline X-270 & Xanthi & bi-hb-granite & $79.6 \pm 1$ & $73.1 \pm 1$ & $915.0 \pm 11$ \\
\hline T-10 & Varnountas & granitic gneiss & $73.2 \pm 1$ & $100.1 \pm 1$ & $970.0 \pm 12$ \\
\hline H-9* & Elatia & alkaligranite & $33.0 \pm 1$ & $124.0 \pm 2$ & $1111.0 \pm 14$ \\
\hline STH-13* & Sithonia & leucogranite & $16.4 \pm 1$ & $18.0 \pm 1$ & $892.0 \pm 11$ \\
\hline L-13 & Varnountas & leucogranite & $58.7 \pm 1$ & $115.6 \pm 2$ & $1113.0 \pm 13$ \\
\hline I-3 & Varnountas & leucogranite & $97.3 \pm 1$ & $104,9 \pm 1$ & $1386.0 \pm 15$ \\
\hline Average & & & $77.3 \pm 1$ & $91.4 \pm 1$ & $929.3 \pm 12$ \\
\hline
\end{tabular}

(qz: quartz, px: pyroxene, bi: biotite, hb: hornblende), * (Karavasili, 2004)

Table 3. Average values of activity concentrations of ${ }^{40} \mathrm{~K},{ }^{226} \mathrm{Ra}$ and ${ }^{232} \mathrm{Th}$ in $\mathrm{Bq} \cdot \mathrm{kg}^{-1}$ of granite samples from different countries of the world.

\begin{tabular}{|l|c|c|c|c|c|}
\hline Country/origin & $\begin{array}{c}\text { No. of } \\
\text { samples }\end{array}$ & ${ }^{40} \mathrm{~K}$ & ${ }^{226} \mathrm{Ra}$ & ${ }^{232} \mathrm{Th}$ & Reference \\
\hline Austria & 1 & 1340 & 40 & 253 & (Chen \& Lin 1996) \\
Belgium & 1 & 1129 & 68 & 77 & (Tzortzis et al., 2003) \\
Brazil & 14 & 1297 & 82 & 168 & (Tzortzis et al., 2003) \\
Brazil & 1 & 1819 & 91 & 152 & (Chen \& Lin 1996) \\
China & 8 & 1256 & 95 & 158 & (Chen \& Lin 1996) \\
Egypt/Wadi Karim & 10 & 4819 & 56 & 54 & (El-Arabi, 2007) \\
Egypt/Um Taghir & 39 & 3918 & 558 & 359 & (El-Arabi, 2007) \\
Egypt/Gable Gattar II & 10 & 1140 & 6018 & 113 & (El-Shershaby, 2002) \\
Egypt/Gable El Majai & 10 & 681 & 198 & 30 & (Arafa, 2004) \\
Egypt/Gable El Misikat & 9 & 705 & 1184 & 40 & (Arafa, 2004) \\
Egypt/Gable El Aradiya & 10 & 480 & 126 & 25 & (Arafa, 2004) \\
Egypt/Homert Waggat North & 10 & 1590 & 489 & 109 & (Arafa, 2004) \\
Egypt/Homert Waggat South & 10 & 2302 & 787 & 163 & (Arafa, 2004) \\
Finland & 3 & 1223 & 94 & 163 & (Chen \& Lin \\
Greece & 49 & 929 & 77 & 91 & (Karavasili et al., 2005 \& \\
& & & & & Present work) \\
Holland & 1 & 1540 & 162 & 490 & (Tzortzis et al., 2003) \\
India & 4 & 1082 & 119 & 172 & (Chen \& Lin 1996) \\
Italy & 1206 & 64 & 91 & (Menager et al., 1993) \\
Malaysia & 1019 & 86 & 134 & (Chen \& Lin 1996) \\
\hline
\end{tabular}


Table 3. Continued

\begin{tabular}{|l|c|c|c|c|c|}
\hline Country/origin & $\begin{array}{c}\text { No. of } \\
\text { samples }\end{array}$ & ${ }^{40} \mathrm{~K}$ & ${ }^{226} \mathrm{Ra}$ & ${ }^{232} \mathrm{Th}$ & Reference \\
\hline Portugal & 1 & 1490 & 117 & 105 & (Chen \& Lin 1996) \\
S. Africa & 1 & 1151 & 92 & 153 & (Chen \& Lin 1996) \\
Spain & 1 & 1289 & 80 & 123 & (Chen \& Lin 1996) \\
Sweeden & 2 & 1226 & 107 & 110 & (Chen \& Lin 1996) \\
Turkey/Kaymaz & 7 & 1266 & 306 & 248 & (Orgun \& Altinsoy, 2005) \\
Turkey/Sivrihisar & 7 & 1058 & 67 & 153 & (Orgun \& Altinsoy, 2005) \\
Pakistan/Ambela & 20 & 1203 & 659 & 598 & (Asghar et al., 2008) \\
& Maximum & 4819 & 6018 & 598 & \\
& Minimum & 480 & 23 & 25 & \\
& Weighted & & & & \\
& Average & 1749 & 567 & 194 & \\
\hline
\end{tabular}

where $\mathrm{C}_{\mathrm{U}}, \mathrm{C}_{\mathrm{Th}}$ and $\mathrm{C}_{\mathrm{K}}$ are the activity concentrations $\left(\mathrm{Bq} \cdot \mathrm{kg}^{-1}\right)$ of $\mathrm{U}$, Th and $\mathrm{K}$ in the samples. The limiting value of this index is $80 \mathrm{nGy} \cdot \mathrm{h}^{-1}(\mathrm{EC}, 1999)$.

2) Annual effective dose $\left(\mathbf{H}_{E}\right)$. The effective dose rate indoors in $\mathrm{mSv}^{\cdot} \mathrm{y}^{-1}(\mathrm{~Sv}=\mathrm{Sievert})$, is calculated by the following formula:

$$
\mathrm{H}_{\mathrm{E}}=10^{-6} \times \mathrm{D} \times \mathrm{T} \times \mathrm{F}
$$

where $\mathrm{D}$ is the calculated dose rate in $\mathrm{nGy} \cdot \mathrm{h}^{-1}, \mathrm{~T}$ is the indoor occupancy time, which implies that $20 \%$ of time is spent outdoors, and is equal to $7000 \mathrm{~h}$, and $\mathrm{F}$ is the doses conversion factor equal to 0.7 Sv $\cdot \mathrm{y}^{-1} \cdot \mathrm{H}_{\mathrm{E}}$ should be $<1 \mathrm{mSv} \cdot \mathrm{y}^{-1}$ (UNSCEAR 1993, 2000).

3) Activity index (AI). Several authors have proposed formulae to estimate this index. In this study it is calculated on the basis of former USSR and W. Germany criterion (Chen \& Lin, 1996):

$$
\mathrm{AI}=\mathrm{C}_{\mathrm{Ra}} / 370+\mathrm{C}_{\mathrm{Th}} / 259+\mathrm{C}_{\mathrm{K}} / 4810
$$

AI should be less than $1 \mathrm{mSv}$.

4) Gamma-ray index $\left(\mathbf{I}_{\gamma}\right)$. European Commission (EC, 1999) has proposed this index which is calculated by the formula:

$$
\mathrm{I}_{\gamma}=\mathrm{C}_{\mathrm{Ra}} / 300 \mathrm{~Bq} \cdot \mathrm{kg}^{-1}+\mathrm{C}_{\mathrm{Th}} / 200 \mathrm{~Bq} \cdot \mathrm{kg}^{-1}+\mathrm{C}_{\mathrm{K}} / 3000 \mathrm{~Bq} \cdot \mathrm{kg}^{-1}
$$

and is correlated with the annual dose rate due to gamma radiation. Materials having $\mathrm{I} \gamma<2$ would increase the annual effective dose by $0.3 \mathrm{mSv}$, while for $2<\mathrm{I} \gamma<6$, the gamma-ray index corresponds to an increase in effective dose by $1 \mathrm{mSv} \cdot \mathrm{y}^{-1}$. Building materials used superficially rather than in bulk amounts (tiles, boards, etc.) should be exempted from all restrictions concerning radioactivity, if the excess of gamma radiation originating from them increases the annual effective dose of a member of public by $0,3 \mathrm{mSv}$ at the most. On the other hand, dose rates higher than $1 \mathrm{mSv} \cdot \mathrm{y}^{-1}$ are allowed only in exceptional cases, where materials are locally used. Finally, samples with $\mathrm{I}_{\gamma}>6$ cannot be recommended for use in buildings (EC, 1999). 
Table 4. Absorbed gamma dose rate $\left(\mathrm{D}_{\mathrm{a}}\right)$, annual effective dose $\left(\mathrm{H}_{\mathrm{E}}\right)$, activity index $\left(\mathrm{A}_{\mathrm{I}}\right)$ and gammaray index $\left(\mathrm{I}_{\gamma}\right)$ for the granites examined.

\begin{tabular}{|c|c|c|c|c|}
\hline sample & $\mathrm{D}_{\mathrm{a}}\left(\mathrm{nGy} \cdot \mathrm{h}^{-1}\right)$ & HE $\left(\mathrm{mSv} \cdot \mathrm{y}^{-1}\right)$ & AI $\left(\mathbf{B q} \cdot \mathbf{k g}^{-1}\right)$ & $\overline{\mathbf{I}_{\gamma}}$ \\
\hline GAE-1 & 31.20 & 0.15 & 0.18 & 0.2 \\
\hline GAE-9 & 80.19 & 0.39 & 0.46 & 0.6 \\
\hline GAE-11 & 13.18 & 0.06 & 0.07 & 0.1 \\
\hline SB-55* & 4.58 & 0.02 & 0.02 & 0.0 \\
\hline NG-5* & 7.85 & 0.04 & 0.05 & 0.1 \\
\hline MP-6 & 110.95 & 0.54 & 0.64 & 0.9 \\
\hline MZ-500* & 243.25 & 1.19 & 1.42 & 1.9 \\
\hline MP-5 & 122.41 & 0.60 & 0.70 & 1.0 \\
\hline KR-9* & 110.60 & 0.54 & 0.63 & 0.9 \\
\hline SB-41* & 169.09 & 0.83 & 0.98 & 1.3 \\
\hline YD-12* & 65.93 & 0.32 & 0.37 & 0.5 \\
\hline L-23* & 100.28 & 0.49 & 0.57 & 0.8 \\
\hline MP-77 & 182.58 & 0.89 & 1.05 & 1.4 \\
\hline P-6* & 192.81 & 0.94 & 1.12 & 1.5 \\
\hline XMZ-501 & 245.64 & 1.20 & 1.44 & 1.9 \\
\hline MP-3 & 157.53 & 0.77 & 0.91 & 1.2 \\
\hline MP-38 & 200.35 & 0.98 & 1.17 & 1.6 \\
\hline MP-53 & 81.73 & 0.40 & 0.47 & 0.6 \\
\hline MR-11* & 146.79 & 0.72 & 0.84 & 1.1 \\
\hline SB-36* & 218.71 & 1.07 & 1.26 & 1.7 \\
\hline DSK-17* & 88.57 & 0.43 & 0.52 & 0.7 \\
\hline D-8b* & 102.34 & 0.50 & 0.59 & 0.8 \\
\hline STH-162 & 70.43 & 0.35 & 0.39 & 0.5 \\
\hline STH-170 & 58.08 & 0.28 & 0.33 & 0.5 \\
\hline STH-5* & 73.00 & 0.36 & 0.41 & 0.6 \\
\hline STH-118* & 113.82 & 0.56 & 0.66 & 0.9 \\
\hline STH-450* & 104.38 & 0.51 & 0.60 & 0.8 \\
\hline D-5* & 88.85 & 0.44 & 0.52 & 0.7 \\
\hline MP-501 & 150.22 & 0.74 & 0.85 & 1.2 \\
\hline P-5 & 122.62 & 0.60 & 0.70 & 1.0 \\
\hline SB-50* & 104.48 & 0.51 & 0.60 & 0.8 \\
\hline L-4* & 108.42 & 0.53 & 0.62 & 0.9 \\
\hline TS-10* & 192.27 & 0.94 & 1.10 & 1.5 \\
\hline G-6* & 155.67 & 0.76 & 0.90 & 1.2 \\
\hline MP-90 & 438.12 & 2.15 & 2.59 & 3.4 \\
\hline STH-6* & 97.88 & 0.48 & 0.56 & 0.8 \\
\hline B-7* & 165.16 & 0.81 & 0.96 & 1.3 \\
\hline D-15* & 163.39 & 0.80 & 0.93 & 1.3 \\
\hline A-13* & 188.02 & 0.92 & 1.07 & 1.4 \\
\hline G-2* & 259.03 & 1.27 & 1.50 & 2.0 \\
\hline PR-27* & 105.93 & 0.52 & 0.60 & 0.8 \\
\hline H-9* & 139.71 & 0.68 & 0.80 & 1.1 \\
\hline STH-13* & 56.33 & 0.28 & 0.30 & 0.4 \\
\hline L-13 & 147.59 & 0.72 & 0.85 & 1.2 \\
\hline I-3* & 171.01 & 0.84 & 0.98 & 1.3 \\
\hline T-10 & 135.33 & 0.66 & 0.78 & 1.1 \\
\hline
\end{tabular}


Table 4. Continued

\begin{tabular}{|l|c|c|c|c|}
\hline \multicolumn{1}{|c|}{ sample } & $\mathbf{D}_{\mathbf{a}}\left(\mathbf{n G y} \cdot \mathbf{h}^{-\mathbf{1}}\right)$ & $\mathbf{H E ~}\left(\mathbf{m S v} \cdot \mathbf{y}^{\mathbf{- 1}}\right)$ & $\left.\mathbf{A I} \mathbf{( B q} \cdot \mathbf{k g}^{-\mathbf{1}}\right)$ & $\mathbf{I}_{\gamma}$ \\
\hline PE-11 & 92.16 & 0.45 & 0.52 & 0.7 \\
\hline TH-5 & 119.01 & 0.58 & 0.67 & 0.9 \\
\hline X-270 & 122.61 & 0.60 & 0.70 & 1.0 \\
\hline Lim. Values & 80 & 1 & 1 & 6 \\
\hline
\end{tabular}

Table 5. Comparison of radiological parameters based upon data available for granite samples from different countries of the world (Asghar et al., 2008).

\begin{tabular}{|c|c|c|c|c|}
\hline Country/origin & $\mathrm{D}_{\mathrm{a}}\left(\mathbf{n G y} \cdot \mathbf{h}^{-1}\right)$ & HE $\left(\mathbf{m S v} \cdot \mathbf{y}^{-1}\right)$ & $\overline{\mathrm{AI}}\left(\mathbf{B q} \cdot \mathrm{kg}^{-1}\right)$ & $\mathbf{I}_{\gamma}$ \\
\hline Africa & 70 & 0.5 & 0.4 & 0.6 \\
\hline Austria & 227 & 0.8 & 1.4 & 1.8 \\
\hline Belgium & 125 & 1.2 & 0.7 & 1.0 \\
\hline Brazil & 193 & 1.2 & 1.1 & 1.5 \\
\hline Brazil & 210 & 1.4 & 1.2 & 1.7 \\
\hline China & 192 & 1.2 & 1.1 & 1.5 \\
\hline Egypt/Wadi Karim & 259 & 1.7 & 1.4 & 2.1 \\
\hline Egypt/Um Taghir & 638 & 0.5 & 3.7 & 5.0 \\
\hline Egypt/Gable Gattar II & 2896 & 17.8 & 16.9 & 21.0 \\
\hline Egypt/Gable El Majai & 138 & 0.5 & 0.8 & 1.0 \\
\hline Egypt/Gable El Misikat & 601 & 3.7 & 3.5 & 4.4 \\
\hline Egypt/Gable El Aradiya & 93 & 0.6 & 0.5 & 0.7 \\
\hline Egypt/Homert Waggat North & 358 & 2.3 & 2.1 & 2.7 \\
\hline Egypt/Homert Waggat South & 558 & 3.5 & 3.2 & 4.2 \\
\hline Finland & 193 & 1.2 & 1.1 & 1.5 \\
\hline Greece* & 131 & 0.6 & 0,8 & 1.0 \\
\hline Holland & 435 & 2.8 & 2.6 & 3.5 \\
\hline India & 204 & 1.3 & 1.2 & 1.6 \\
\hline Italy & 135 & 0.9 & 0.8 & 1.1 \\
\hline Malaysia & 163 & 1.0 & 1.0 & 1.3 \\
\hline Portugal & 180 & 1.2 & 1.0 & 1.4 \\
\hline S. Africa & 183 & 1.2 & 1.1 & 1.5 \\
\hline Spain & 165 & 1.1 & 1.0 & 1.3 \\
\hline Sweeden & 166 & 1.1 & 1.0 & 1.3 \\
\hline Turkey/Kaymaz & 344 & 2.2 & 2.0 & 2.7 \\
\hline Turkey/Sivrihisar & 167 & 1.1 & 1.0 & 1.3 \\
\hline Pakistan/Ambela & 716 & 4.5 & 4.3 & 5.6 \\
\hline Limits & 80 & 1 & 1 & 6 \\
\hline Average & 455 & 2.2 & 2,7 & 3,4 \\
\hline Maximum & 2896 & 17.8 & 16.9 & 21.0 \\
\hline Minimum & 70 & 0.5 & 0.4 & 0.6 \\
\hline
\end{tabular}

*present study/ 
The $\mathrm{D}_{\mathrm{a}}, \mathrm{H}_{\mathrm{E}}, \mathrm{AI}$ and $\mathrm{I}_{\gamma}$ values obtained for the samples of the present study along with their limiting values are presented in Table 4.

The radiological parameters of the basic samples studied (GAE-1, GAE-9, GAE-11, SB-55, NG-5 and MP-6) seem to be below the international dose limiting values. On the other hand, the radiological parameters for two granite samples (MP-90 and G-2 from Maronia and Granitis, respectively) appear to be above limits in all cases except for $\mathrm{I}_{\gamma}$.

From the worldwide activity concentration data given in Table 3, hazard indices, as defined above, have been calculated and are given in Table 5 .

Among the 27 countries/locations selected for comparison, granite of 7 countries (including Greece) fulfill the criterion of $\mathrm{H}_{\mathrm{E}}<1$ to be used as building materials. Moreover, the average $\mathrm{H}_{\mathrm{E}}$ of Greek samples is very close to the minimum $\mathrm{H}_{\mathrm{E}}$ found. However, since granites are usually used in small quantities in house buildings, they do not induce an activity level exceeding the $1 \mathrm{mSv} \cdot \mathrm{y}^{-1}$ dose limit (Pavlidou et al., 2006). As far as the AI is concerned, the average value of the samples studied is half than the 'world' average as it was calculated in this report. Finally, considering the values of gammaray index granites from Greece have the fourth lowest value. Only one of the selected countries/locations does not fulfil the criterion of $\mathrm{I}_{\gamma}<6$, and consequently, its use as building material is not recommended. This is the case of Gable Gattar II granite in Egypt, where there is U mineralization with high economic potential (El-Shershaby, 2002).

As the research on the natural radioactivity of the greek granites is in progress it must be noted here that the present results are considered as preliminary.

\section{Conclusions}

Twenty granite samples from northern Greece have been measured for their natural radioactivity in order to asses the radiological impact in case they are used as building materials, while 29 more samples were obtained from a previous study. The activities of ${ }^{40} \mathrm{~K},{ }^{226} \mathrm{Ra}$ and ${ }^{232} \mathrm{Th}$ of the majority of the samples exceed the average level of these radionuclides in soil and building materials. That is because granites contain $U$ and Th-rich minerals in them. Samples of basic composition have very low concentrations of radionuclides, which reflect to the values of their hazard indices that are below limits. On the other hand, intermediate and acid rocks are more enriched in ${ }^{40} \mathrm{~K},{ }^{226} \mathrm{Ra}$ and ${ }^{232} \mathrm{Th}$ and their decay products. Four hazard indices were calculated in order to assess the health risk of using the above samples as building materials. The average of hazard indices of Greek granites is below 'world' average in all cases. Moreover, it is still bellow the criteria of UNSCEAR (2000). Therefore, at least from radiological point of view and for the investigated rocks, the use of granites from northern Greece as building materials is recommended.

\section{References}

Adams J.A.S., Osmond Y.K. and Rogers J.J.W., 1959. The geochemistry of uranium and thorium. Phys. Chem. Earth 3, 298-343.

Anjos R.M, Veiga R., Soares T.,. Santos A.M.A, Aguiar J.G., Frasca M.H.B.O., Brage J.A.P., Uzeda D., Mangia L., Facure A., Mosquera B., Carvalho C., Gomes P.R.S., 2005. Natural radionuclide distribution in Brazilian commercial granites. Radiation Measurements 39, 245 - 253.

Arafa W., 2004. Specific activity and hazards of granite samples collected from the eastern desert of Egypt. J. Environ. Radioactivity. 75, 315-327.

Asghar M., Tufail M., Javied S., Abid A. and Waqas M., 2008. Radiological implications of granite of 
northern Pakistan. Journal of Radiological Protection 28, 387-399.

Chen C.J., Lin Y.M., 1996. Assessment of building materials for compliance with regulations of ROC. Environment International 22, 221-226.

Christofides, G., Soldatos, T., Eleftheriadis, G. and Koroneos, A., 1998. Chemical and isotopic evidence for source contamination and crustal assimilation in the Hellenic Rhodope plutonic rocks. Acta Vulcanologica, 10(2), 305-318.

Christofides G., Koroneos A., Pe-Piper G., Katirtzoglou K., Chatzikirkou, 1999. Pre-Tertiary A-Type magmatism in the Serbomacedonian massif (N. Greece): Kerkini granitic complex. Bulletin of the Geological Society of Greece vol. XXXIII, 131-148.

D’Amico C., Christofides G., Eleftheriadis G., Bargossi G.M., Campana R., Soldatos T., 1990. The Sithonia Plutonic Complex (Chalkidiki, Greece). Miner. Petrogr. Acta vol. XXXIII, 143-177.

El-Arabi A.M., 2007. Ra, Th, K concentrations in igneous rocks from eastern desert Egypt and its radiological implications. Radiat. Meas. 42, 94-100.

El-Shershaby A., 2002. Study of radioactivity levels in granite of Gable-Gattar II in the north eastern desert of Egypt. Appl. Radiat. Isot. 57, 131-135.

European Commission (EC), 1999. Radiation Protection 112 : Radiological Protection Principles Concerning the Natural Radioactivity of Building Materials Directorate -General Environment, Nuclear Safety and Civil Protection.

Faure G., 1986. Principles of Isotope Geology, second ed. John Wiley \& Sons, London, 464 pp.

Grigoriadou A., Koroneos A., Eleftheriadis G., 2003. Mineralogy of Kastoria pluton, Bulletin of the Geological Society of Greece vol. XXXV, 46-60.

International Union of Geological Sciences (I.U.G.S.), 1973. Subcommision on the systematic of igneous rocks. Classification and nomenclature of plutonic rocks. N. Jb. Min. Mh., 1973, 149-163.

Karavasili E., 2004. Mineralogy, Petrology and Radioactivity of Greek granitic rocks. MSc Thesis, School of Geology, Aristotle University of Thessaloniki, 98 pp. (in Greek).

Karavasili E., Christofides G., Papastefanou C., Koroneos A. and Stoulos S., 2005. Mineralogy, Petrography and Radioactivity of Greek Granites. Proceedings of the 2nd Congress of the Committee of the Economic Geology, Mineralogy \& Geochemistry of the Geological Society of Greece, Thessaloniki, 123-132.

Koroneos A., 1991. Mineralogy, petrology and geochemistry of the Eastern Varnountas plutonite (NW Macedonia). Ph.D. thesis, Univeristy of Thessaloniki, 450pp (in Greek with English abstract).

Menager M.T., Heath M.J., Ivanovich M., Montjotin C., Barillon C.R., Camp J. and Hasler S.E., 1993. Migration of uranium from uranium-mineralised fractures into rock matrix in granite: implications for radionuclide transport around a radioactive waste repository. Radfiochem. Acta 66/67 47-83.

Orgun Y. and Altinsoy N., 2005. Natural radioactivity levels in granitic plutons and groundwaters in southeast part of Eskisehir, Turkey. Appl. Radiat. Isot. 63, 267-275.

Pakou A.A., Assimakopoulos P.A. and Prapidis M., 1994. Natural radioactivity and radon emanation factors in building materials used in Epirus (north-west Greece). Science of the Total Environment 144, 255-260.

Papastefanou C., Manolopoulou M. and Charalambous S., 1984. Exposure from the radioactivity in building materials. Health Physics 47, 775-783.

Pavlidou S., Koroneos A., Papastefanou C., Christofides G., Stoulos S., Vavelides M., 2006. Natural radioactivity of granites used as building materials. Journal of Environmental Radioactivity 89, 48-60.

Petropoulos N.P., Anagnostakis M.J. and Simopoulos S.E., 2002. Photon attenuation, natural radioactivity content and radon exhalation rate of building materials. Journal of Environmental Radioactivity 
61, 257-269.

Savidou A., Raptis C. and Kritidis P., 1995. Natural radioactivity and radon exhalation from building materials used in Attica region, Greece. Radiation Protection Dosimetry 59, 309-312.

Siotis I. and Wrixon A.D., 1984. Radiological consequences of the use of fly ash in building materials in Greece. Radiation Protection Dosimetry 7, 101-105.

Soldatos T., 1985. Petrology and geochemistry of the Elatia pluton. Ph.D. Thesis, University of Thessaloniki, Greece, 303 p., (in Greek with English abstract).

Stoulos S., Manolopoulou M., Papastefanou C., 2003. Assessment of natural radiation exposure and radon exhalation from building materials in Greece. Journal of Environmental Radioactivity 69, 225-240.

Tzortzis M., Tsertos H., Christofides S., Christodoulides G., 2003. Gamma measurements and dose rates in commercially used tiling rocks (granites). Journal of Environmental Radioactivity 70, 223-235.

United Nations Scientific Committee on the Effects of Atomic Radiation (UNSCEAR), 1993. Sources and Effects of Ionizing Radiation. United Nations, New York.

United Nations Scientific Committee on the Effects of Atomic Radiation (UNSCEAR), 2000. Sources and Effects of Ionizing Radiation, Vol .I. United Nations, New York. 